EISSN: $2706-7947 \quad$ ISSN: $2077-4613$

DOI: 10.36632/mejas/2021.11.2.39

Journal homepage: www.curresweb.com

Pages: 472-480

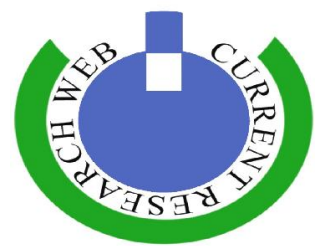

\title{
Irrigation Intervals Capacity and Acorbic Acid Treatments on Optimize Growth, and Chemical Constituents of Tecoma Capensis L. Plants
}

\author{
Nahed G. Abdel-Aziz', Mona H. Mahgub', Azza A. Mazher', Mona A. Darwish² and \\ Ahmed S. Abdel-Aal ${ }^{1}$
}

${ }^{I}$ Department of Ornamental Plants and Woody Trees, Agricultural \& Biological Research Division, National Research Centre (NRC), 33 El-Buhouth St., 12622 Dokki, Giza, Egypt

${ }^{2}$ Department of Ornamental Horticulture, Faculty of Agriculture, Cairo University, Giza, Egypt.

Received: 10 April $2021 \quad$ Accepted: 15 May Published: 20 May 2021

\begin{abstract}
The present study was carried out at the Ornamental Horticulture Department, Faculty of Agriculture, Cairo University, Giza, during the two successive seasons of 2014 and 2015 in order to enhancement the growth of Tecoma plants grown under different concentrations of foliar application of ascorbic acid (200 and $400 \mathrm{ppm}$ ) and irrigation intervals (3,5 and 7 days). The results showed that irrigation intervals at 3 days gave the highest values of all growth parameters except root length, fresh and dry weight of roots which increased when plants were treated with irrigation intervals at 7 days. The same treatment increased the chemical constituents except $\mathrm{N} \%$ in roots, $\mathrm{P} \%$ in branches and roots, $\mathrm{K} \%$ in branches and roots, carbohydrates \% in roots. Application of ascorbic acid at $400 \mathrm{ppm}$ gave the highest values of the most growth parameters and chemical constituents, followed by ascorbic acid at $200 \mathrm{ppm}$. The application of ascorbic acid at $400 \mathrm{ppm}$ under irrigation intervals at 3 days gave the highest values of growth parameters and chemical constituents in both seasons.
\end{abstract}

Keywords: Tecoma capensis, irrigation intervals, ascorbic acid, Growth, chemical contents

\section{Introduction}

Tecoma capensis is an ornamental garden plant commonly used for screening and decorative purposes. It can also be trimmed to form a hedge. It is often planted specifically to attract birds and butterflies. The powdered bark of this attractive garden plant is used as a traditional medicine to relieve pain and sleeplessness (Thomposon, 2001). Tecoma capensiscan be used as a climbing vine (it needs typing) or barrier hedge/screen, trained as a specimen shrub, or used a ground cover on steep slopes or rocky banks. It is sometimes trained as an espalier. It is especially attractive cascading over walls or planters. It can bet retrained to a garden arch. Tecoma capensis is tolerant of salt spray and accepts acidic to alkaline coils (Steve 2003).

Water is one of the most abundant compounds on the ground as $2 / 3$ of the ground-level was surrounded or covered with water, but in most part of the world, lack (shortage) of water is a factor which is limit the production of the agricultural products (Reddy et al., 2004). Lack (shortage) of water in Egypt is accounted as a factor which limit the plantation and growth of the agricultural plants. Plants offend suffer from water deficit stress, and the severity of the resulting damage varies depending on the intensity and duration of the stress. Other than the apparent effects of drought stress, the effects of water deficit are not well understood at the biochemical and molecular levels (Abd-Elbaki et al., 200; Bismillah et al., 2001 and Reddy et al., 2004). Various physiological practices are applied to alleviate the adverse effect of water deficit stress on the normal functioning of plants (Campos et al., 204; Darvishan et al., 2013 and Yoghoubian et al., 2014).

Vitamins could be regarded as compounds of bioregulators or hormone precursors that, in tiny amounts employ a valuable impact on plant growth and development. Overall, these substances could affect the energy metabolic pathway (Rady et al., 2015; Dawood et al., 2016 and Orabi and Abdelhamid,

Corresponding Author: Nahed G. Abdel-Aziz, Department of Ornamental Plants and Woody Trees, National Research Center, Giza, Egypt 
2016). All essential physiological processes, such as photosynthesis, biosynthesis enzymes and secondary metabolites, nutrient and water absorption, and cell division more or less depend on vitamin availability. In the defense of plats in resistance to oxidative stress, vitamins with their antioxidant properties also play an important role as free radical scavengers. Vitamins have favourable effect on enhancing cell division and phytohormone synthesis, for instance cytokines and gibberellins (Abdelhamid et al., 2013). Ascorbic acid (AsA) functions as an antioxidant, an enzyme cofactor, and as a pre-cursor for oxalate and tartrate synthesis. AsA is affiliated with chloroplasts in which the effect of oxidative stress on photosynthesis is mitigated. Furthermore, the alteration of cell division and works as a primary substrate in the cyclic pathway of hydrogen peroxide enzymatic detoxification (Beltaji, 2008).

Certain water management practices, e.g., irrigation can contribute to the sustained growth in low soil water environments; therefore, recognizing the effects of AsA an managing antioxidant metabolism systems and other physiological and biochemical processes is crucial in developing successful practices to enhance plant tolerance to water stress. The research hypothesis we verified is that ascorbic acid alleviates water stress tolerance of plants and we can point physiological and biochemical determinants of this tolerance. The purpose of this work is also to examine the efficiency of foliar-applied AsA dose for counteracting the drought stress in Tecoma capensis seedlings.

\section{Materials and Methods}

This study has been carried out at the Ornamental Horticulture Department, Faculty of Agriculture, Cairo University, Giza. during the two successive seasons 2014 and 2015 to investigate the effect of ascorbic acid under stress conditions on growth and chemical constituents of Tecoma capensis seedlings.

The laborarity work on ornamental and woody trees department - National Research Center.

\section{Plant material}

Seedlings of Duranta erecta and Tecoma capensis were obtained from (private farm) (six month old, $20 \mathrm{~cm}$ height) were used as a plant material. The experiment was under open field conditions through the two seasons.

\section{Soil media treatments}

The seedlings of Tecoma capensis were cultivated $(20 \mathrm{~cm}$ length) in the first week of March in both seasons, and transported in $30 \mathrm{~cm}$ pots during the second week of March 2014 and 2015. The soil use was a combine with sand and compost $2: 1(\mathrm{~V}: \mathrm{V})$. All agricultural operations procedure especially fertilize all plants with Kristalon (NPK 19:19:19), produced by Phayzon Company, Holland at the rate of $5 \mathrm{gm} /$ pot used in three times through the growth season; The plants were located under open field condition and irrigation was done according to the plants need. The physical and chemical analysis of these growing media presented in Table (1).

Table 1: Physical and chemical analysis of the growing media used in the experiment.

A. Physical analysis

\begin{tabular}{|c|c|c|c|c|c|c|c|c|}
\hline \multirow{2}{*}{\multicolumn{3}{|c|}{ Medium material }} & \multirow{2}{*}{ SP \% } & \multicolumn{2}{|c|}{ F.C } & \multirow{2}{*}{ W.P \% } & \multirow{2}{*}{\multicolumn{2}{|c|}{ A.W \% }} \\
\hline & & & & 0.1 & 0.33 & & & \\
\hline \multirow{3}{*}{\multicolumn{3}{|c|}{$\begin{array}{l}\text { Virgin sandy sample } \\
\text { Mixed (sand + compost ) sample } \\
\text { Compost sample }\end{array}$}} & 35.9 & 7.7 & 6.2 & 2.2 & \multicolumn{2}{|c|}{5.5} \\
\hline & & & 49.8 & 33.7 & 24.8 & 9.5 & \multicolumn{2}{|c|}{24.2} \\
\hline & & & 75.3 & 56.1 & 48.3 & 16.3 & \multicolumn{2}{|c|}{39.8} \\
\hline \multicolumn{9}{|c|}{ B. Chemical analysis } \\
\hline \multirow{2}{*}{$\begin{array}{c}\mathrm{EC} \\
(\mathrm{dS} / \mathrm{m})\end{array}$} & \multirow{2}{*}{ pH } & \multicolumn{5}{|c|}{ Ions species (meq/L) } & \multirow[b]{2}{*}{$\mathrm{Cl}^{-}$} & \multirow[b]{2}{*}{$\mathrm{SO}_{4}^{--}$} \\
\hline & & $\mathbf{C a}^{++}$ & $\mathbf{M g}^{++}$ & $\mathrm{Na}^{+}$ & $\mathbf{K}^{+}$ & $\left(\mathrm{CO}_{3}^{--}+\mathrm{HCO}_{3}^{-}\right)$ & & \\
\hline 0.54 & 7.65 & 0.5 & 1.4 & 3.5 & 0.5 & 1.7 & 0.6 & 3.2 \\
\hline
\end{tabular}

The field capacity was $1300 \mathrm{~cm}^{3} /$ pot. The irrigation schedule was three treatments (every 3,4 or 5 days). After one month from transplanting, the irrigation regime was started and was terminated in 
$15^{\text {th }}$ November. Three concentrations of foliar spray of ascorbic acid at $(0,200$ and $400 \mathrm{ppm})$ were used (obtained from Agricultural Company under control of Ministry of Agriculture, Egypt). The seedlings received the first application with ascorbic acid after two weeks of the start of irrigation regime and the second application after two weeks from the first application.

The following data were recorded: plant height $(\mathrm{cm})$, root length $(\mathrm{cm})$, branches number/plant, fresh and dry weight of branches and roots (g/plant). The experiment was sitting in completely randomized in factorial experiment design with three irrigation intervals and spraying with three concentrations of ascorbic acid to give 15 treatments with 3 replicates. Each replicates contained five plants.

The experiments of this investigation was carried out at the Ornamental Horticulture Department, Faculty of Agriculture, Cairo University, Giza. The following data were recorded on December $15^{\text {th }}$ 2014and 2015 at the end of the growth period.

The following chemical analysis was determined pigments content (chlorophyll a,b and total carotenoids)mg/g F.W. were determined in leaf samples according to the method by Nornai(1982). Total carbohydrates (\% D.W.) in the leaves were determined using the method according to Dubois et al., (1956). Elements determination by digestion of samples, elements extraction was prepared according to (Piper, 1950). Nitrogen (\%D.W.) was determined by modified kyeldahl method as described by Cattenie et al., (1982). Phosphorus (\%D.W.) was estimated using ammonium molybdate method according to Snell and Snell (1949). Potassium content was measured by flam photometer according to Chapman and Pratt (1978).

\section{Statistical analysis}

A randomize complete block design with two factor was used for analysis vegetative growth with three replications for each parameter. The treatment means were compared by least significant difference (L.S.D.) test as given by Snedecor and Cochran (1976) by used Assistat program.

\section{Results and Discussion}

\subsection{Vegetative growth}

Results recorded in the two seasons (Tables 2-4) reported that significant decrease was detected in all above ground vegetative growth including, plant height, number of branches/plant, fresh and dry weight of branches in the first season, the same results were obtained in the second season except branches number/plant as a result of increasing intervals between irrigation.

The highest values for all these parameters were observed due to the use of irrigation every 3 days. The depressive effect of water stress on growth parameters could be attributed to the drop in leaf water content and the reduction in the assimilation of nitrogen compounds (Reddy et al., 2004). It also, affect the rate of cell division and enlargement. Drought stress also reduced the of essential elements and affected photosynthetic capacity as well as induced excessive accumulation of intermediate compounds such as reactive oxygen species (Khalifa et al., 2002 and El-Sobky et al., 2004), which cause oxidative damage to DNA, lipid and proteins and consequently a decrease in plant growth. Finally, water stress leads to increases in abscisic acid cause an inhibition of the growth. The enhanced production of reactive oxygen species (ROS) during water stress lead to the progressive oxidative damage and ultimately cell death and growth suppression (Araus et al., 2012). On the contrary, root length and fresh and dry weights of roots gave an apposite manner which they gradually increased with irrigation intervals increase. Numerically, root length, fresh and dry weight of root were increased by $0.39,0.33$ and $0.38 \%$ in the first season and by $0.24,0.33$ and $0.38 \%$ with irrigation every 7 days, respectively in comparison with irrigation every 3 days. The lower water supply causes the root system to penetrated deeper and extending wider in the soil with higher root system researching for moisture in lower. These results were online with those reported by Azza et al., (2010< Azza et al., (2012) and Hashich et al., (2014).

The data in the same tables revealed that all growth parameters i.e. plant height, root length, branches number/plant, fresh and dry weight of root and branches of Tecoma capensis were positive affected by ascorbic acid at 200 and $400 \mathrm{ppm}$ compared to control plants. In both seasons, the highest values of plant height, root length and branches number/plant except root length in the second seasons were recorded with plants treated with $400 \mathrm{ppm}$ ascorbic acid compared with control or other treatment 
in the two seasons. But, in the first season, the heaviest fresh and dry weight branches and roots was obtained by ascorbic acid at $200 \mathrm{ppm}$. In the second season the some result was obtained by ascorbic at $200 \mathrm{ppm}$ for fresh and dry weight for branches whereas ascorbic acid at $400 \mathrm{ppm}$ gave the heaviest fresh and dry weights of roots. Regarding ascorbic acid, Price (1966) reported that is the most abundant antioxidant which protect plant cell and currently considered to regulators on plant growth owing to its effect on cell division and differentiation. The incrementing growth parameters due to ascorbic acid are largely due to stabilize member structures Blokhina et al., (2003), modulating membrane phidity in a similar manner to cholesterol and also membrane permeability to small ions and molecules (Foyer, 1992). In this respect, Simiranoff (1966) reported that ascorbate has been implicated in regulation of cell division.

Table 2: Effect of irrigation intervals and ascorbic acid on plant height $(\mathrm{cm})$, root length $(\mathrm{cm})$ and branches number/plant of Tecoma capensis L. plants.

\begin{tabular}{|c|c|c|c|c|c|c|}
\hline \multirow{2}{*}{$\begin{array}{l}\text { Season } \\
\text { Characters } \\
\text { Treatments }\end{array}$} & \multicolumn{3}{|c|}{ First season } & \multicolumn{3}{|c|}{ Second season } \\
\hline & $\begin{array}{c}\text { Plant } \\
\text { height }(\mathrm{cm})\end{array}$ & $\begin{array}{c}\text { Root } \\
\text { length }(\mathrm{cm})\end{array}$ & $\begin{array}{c}\text { Branches } \\
\text { number/plant }\end{array}$ & $\begin{array}{c}\text { Plant height } \\
(\mathrm{cm})\end{array}$ & $\begin{array}{c}\text { Root length } \\
(\mathrm{cm})\end{array}$ & $\begin{array}{c}\text { Branches } \\
\text { number/plant }\end{array}$ \\
\hline 3 D & 152.11 & 41.23 & 20.63 & 167.61 & 51.78 & 32.33 \\
\hline $5 \mathrm{D}$ & 118.67 & 51.00 & 17.78 & 156.28 & 63.34 & 27.00 \\
\hline $7 \mathrm{D}$ & 112.61 & 57.11 & 16.56 & 128.89 & 64.44 & 27.89 \\
\hline LSD at 0.05 & 1.82 & 0.57 & 6.40 & 5.28 & 3.04 & 2.97 \\
\hline Control & 113.05 & 48.22 & 15.78 & 123.28 & 56.78 & 26.33 \\
\hline 200 ppmAS & 127.56 & 49.44 & 17.78 & 162.99 & 61.44 & 27.45 \\
\hline 400ppmAS & 142.78 & 51.68 & 21.44 & 166.5 & 61.33 & 33.44 \\
\hline LSD at 0.05 & 1.80 & 0.58 & 0.41 & 5.27 & 5.26 & 2.97 \\
\hline 3D*0ppmAS & 119.33 & 39.00 & 17.68 & 130.68 & 47.68 & 28.68 \\
\hline 3D*200ppmAS & 152.68 & 42.00 & 21.63 & 177.33 & 54.33 & 31.00 \\
\hline 3D*400ppmAS & 184.33 & 42.68 & 22.68 & 194.83 & 53.33 & 37.33 \\
\hline 5D*0ppmAS & 116.33 & 50.33 & 15.00 & 115.50 & 59.68 & 26.33 \\
\hline 5D*200ppmAS & 117.00 & 50.00 & 17.00 & 186.33 & 63.68 & 23.68 \\
\hline 5D*400ppmAS & 122.68 & 52.68 & 21.33 & 167.00 & 66.62 & 31.00 \\
\hline 7D*0ppmAS & 103.50 & 55.33 & 14.68 & 123.68 & 63.00 & 24.00 \\
\hline 7D*200ppmAS & 113.00 & 56.33 & 14.68 & 125.33 & 66.33 & 27.68 \\
\hline 7D*400ppmAS & 121.33 & 59.68 & 16.56 & 137.68 & 63.00 & 32.00 \\
\hline LSD at 0.05 & 3.15 & 1.00 & 0.72 & 9.14 & 5.26 & 5.14 \\
\hline
\end{tabular}

Table 3: Effect of irrigation intervals and ascorbic acid on fresh weight of branches and roots of Tecoma capensis L. plants.

\begin{tabular}{lcccc}
\hline Season & \multicolumn{4}{c}{ First Season } \\
\cline { 2 - 5 } Treatments & $\begin{array}{c}\text { F.W. of Branches } \\
\text { (g/plant) }\end{array}$ & $\begin{array}{c}\text { F.W. of Roots } \\
\text { (g/plant) }\end{array}$ & $\begin{array}{c}\text { D.W. of Branches } \\
\text { (g/plant) }\end{array}$ & $\begin{array}{c}\text { D.W. of Roots } \\
\text { (g/plant) }\end{array}$ \\
\hline 3 Days & 95.15 & 39.32 & 34.45 & 16.25 \\
5 Days & 91.15 & 38.09 & 32.76 & 15.80 \\
7 Days & 79.91 & 52.36 & 27.96 & 22.42 \\
LSD at 0.05 & 4.61 & 8.51 & 2.05 & 1.05 \\
Control & 80.23 & 39.70 & 28.03 & 16.53 \\
200 ppm AS & 96.87 & 49.08 & 35.25 & 20.75 \\
400 ppm AS & 89.26 & 40.99 & 31.89 & 17.18 \\
LSD at 0.05 & 4.60 & 8.50 & 2.05 & 1.06 \\
3D*0ppmAS & 87.28 & 41.30 & 30.70 & 17.00 \\
3D*200ppmAS & 101.30 & 42,53 & 37.48 & 17.83 \\
3D*400ppmAS & 96.88 & 34.13 & 35.18 & 13.93 \\
5D*0ppmAS & 83.40 & 29.68 & 29.20 & 12.00 \\
5D*200ppmAS & 98.40 & 41.70 & 36.00 & 17.33 \\
5D*400ppmAS & 92.10 & 42.90 & 33.08 & 18.08 \\
7D*0ppmAS & 70.03 & 48.13 & 24.18 & 20.60 \\
7D*200ppmAS & 90.90 & 63.00 & 32.28 & 27.10 \\
7D*400ppmAS & 78.80 & 45.95 & 27.43 & 19.55 \\
\hline LSD at 0.05 & 9.10 & 14.73 & 3.55 & 1.83 \\
\hline
\end{tabular}


Table 4: Effect of irrigation intervals and ascorbic acid on dry weight of branches and roots of Tecoma capensis L. plants.

\begin{tabular}{lcccc}
\hline Season & \multicolumn{4}{c}{ Second Season } \\
\cline { 2 - 5 } Characters & $\begin{array}{c}\text { D.W. of } \\
\text { Branches } \\
\text { (g/plant) }\end{array}$ & $\begin{array}{c}\text { D.W. of Roots } \\
\text { (g/plant) }\end{array}$ & $\begin{array}{c}\text { D.W. of Branches } \\
\text { (g/plant) }\end{array}$ & $\begin{array}{c}\text { D.W. of Roots } \\
\text { (g/plant) }\end{array}$ \\
\hline 3 Days & 114.39 & 51.03 & 44.98 & 22.43 \\
5 Days & 106.53 & 53.47 & 40.92 & 23.78 \\
7 days & 99.69 & 63.12 & 37.91 & 28.69 \\
LSD at 0.05 & 5.50 & 9.82 & 3.09 & 2.32 \\
Control & 97.18 & 47.62 & 36.59 & 20.89 \\
200 ppmAS & 113.66 & 55.37 & 44.51 & 24.67 \\
400 ppmAS & 109.78 & 64.63 & 42.71 & 29.35 \\
LSD at 0.05 & 5.50 & 8.50 & 3.09 & 2.31 \\
3D*0ppmAS & 106.43 & 43.13 & 40.68 & 18.53 \\
3D*200ppmAS & 121.10 & 55.30 & 48.45 & 24.62 \\
3D*400ppmAS & 115.65 & 54.65 & 45.83 & 24.16 \\
5D*0ppmAS & 96.70 & 44.23 & 36.30 & 19.21 \\
5D*200ppmAS & 109.45 & 53.08 & 42.13 & 23.29 \\
5D*400ppmAs & 113.43 & 63.10 & 44.33 & 28.84 \\
7D*0ppmAS & 88.40 & 55.50 & 32.80 & 24.93 \\
7D*200ppmAS & 110.43 & 57.73 & 42.95 & 26.10 \\
7D*400ppmAS & 100.25 & 76.13 & 37.98 & 35.04 \\
LSD at 0.05 & 9.61 & 17.01 & 5.36 & 4.01 \\
\hline
\end{tabular}

In this connection, who also pointed out that cell wall ascorbate and cell wall localized ascorbate oxidase has been implicated in control growth, high associate oxide activity is associated with rapidly expanding cells. Accordingly, these increments in the growth parameters by ascorbic acid. The present observation are fully corporate the finding of El-Fawakhry and El-Tayeb (2003) on chrysanthemum, Youssef et al., (2004) ondatura a plants, Mona and Iman (2005) on rose geranium and Azza et al. (2011) on Codiaeum variegatum plants.

The interaction between different involved factors (irrigation and ascorbic acid) were almost significant for vegetative growth characters. The highest values due to the irrigation regimes and ascorbic acid were obtained due (3 days and $400 \mathrm{ppm}$ ascorbic acid) for plant height, branches number/plant, fresh and dry weight of branches in both seasons. (On the other hand, the heaviest fresh and dry weight of root was obtained by irrigated plants every 7 days $+200 \mathrm{ppm}$ ascorbic acid in the first season, but in the second season, irrigate plants every 7 days $+400 \mathrm{ppm}$ ascorbic acid gave the heaviest fresh and dry weight of roots. Yoghoubian et al., (2014) pound that, application of Vitamin C (ascorbic acid) was effective to mitigate the adverse effect of abiotic stress on plant growth.

\subsection{Chemical composition}

\subsubsection{Pigments content (mg/g F.W.)}

From the given data in Table (5) it can be concluded that, increasing irrigation intervals caused an increase in the content of photosynthetic pigments (Chlorophyll a,b and carotenoids). Accordingly it can be stated that irrigation every 3 days was the most effective irrigation treatment for promoting the synthesis and accumulation of the three photosynthetic pigments. In harmony with these results were those obtained by Azza et al., (2007) on Bauhinia variegate seedlings, Farahat et al., (2012) on Khaya senegalensisseedlings and Hoshish et al., (2014) on Jatropha curcas seedlings. In this respect, the two concentrations used of ascorbic acid cosed an an increase in the contents of chlorophyll a,b and carotenoids in regard to those of untreated seedlings.

This results are in agreement with Mervat et al., (2010) and Abou-Leila et al., (2012) on Jatropha plants, and may be due to modulating membrane of fluidity in similar manner to cholesterol and also ascorbic acid have in membrane permeability to ions and molecule (Foyer 1992), stabilize membrane structure Blokhina et al., (2002). Concerning the interaction between irrigation intervals and ascorbic acid applications, the daa revealed that irrigation every 3 days + spraying with ascorbic acid at $400 \mathrm{ppm}$ recorded the highest values of chlorophyll $\mathrm{a}$ and $\mathrm{b}$ in both seasons but irrigation every 3 days plus 
spraying with ascorbic acid at $200 \mathrm{ppm}$ gave the highest value of carotenoids on the first and second seasons, in comparison with the other treatments.

Table 5: Effect of irrigation intervals and ascorbic acid on pigments content (mg/g F.W.) and total carbohydrates(\%) of Tecoma capensis L. plants.

\begin{tabular}{|c|c|c|c|c|c|c|c|c|}
\hline \multirow{2}{*}{$\begin{array}{c}\text { Characters } \\
\text { Treatments } \\
\end{array}$} & \multicolumn{3}{|c|}{ Pigments content $1^{\text {st }} \mathrm{mg} / \mathrm{gF} . \mathrm{W}$. } & \multicolumn{3}{|c|}{ Pigments content $2^{\text {nd }} \mathrm{mg} / \mathrm{g}$ F.W. } & \multicolumn{2}{|c|}{ Total carbohydrates $(\%)$} \\
\hline & Chl. a & Chl.b & carotenoids & Chl.a & Chl.b & carotenoids & $1^{\text {st }}$ & $2^{\text {nd }}$ \\
\hline 3 Days & 0.91 & 0.33 & 0.41 & 1.02 & 0.35 & 0.51 & 34.63 & 41.25 \\
\hline 5 Days & 0.76 & 0.29 & 0.34 & 0.90 & 0.33 & 0.45 & 30.54 & 39.19 \\
\hline 7 Days & 0.67 & 0.25 & 0.29 & 0.78 & 0.30 & 0.40 & 25.60 & 35.40 \\
\hline Control & 0.67 & 0.25 & 0.31 & 0.80 & 0.29 & 0.42 & 28.28 & 35.82 \\
\hline 200ppm AS & 0.80 & 0.29 & 0.37 & 0.90 & 0.33 & 0.49 & 33.58 & 42.23 \\
\hline 400ppm AS & 0.87 & 0.33 & 0.35 & 1.00 & 0.37 & 0.44 & 28.91 & 37.78 \\
\hline $3 D * 0$ ppmAS & 0.85 & 0.28 & 0.35 & 0.93 & 0.32 & 0.46 & 31.92 & 32.65 \\
\hline $3 \mathrm{D} * 200 \mathrm{ppmAS}$ & 0.90 & 0.33 & 0.45 & 1.01 & 0.35 & 0.55 & 39.29 & 48.01 \\
\hline $3 \mathrm{D} * 400 \mathrm{ppmAS}$ & 0.97 & 0.37 & 0.41 & 1.11 & 0.39 & 0.52 & 32.69 & 43.08 \\
\hline 5D*0ppmAS & 0.62 & 0.24 & 0.32 & 0.78 & 0.29 & 0.42 & 27.13 & 34.08 \\
\hline $5 \mathrm{D} * 200 \mathrm{ppmAS}$ & 0.85 & 0.29 & 0.36 & 0.92 & 0.33 & 0.48 & 35.09 & 44.99 \\
\hline $5 \mathrm{D} * 400 \mathrm{ppmAS}$ & 0.80 & 0.33 & 0.34 & 1.01 & 0.37 & 0.44 & 29.41 & 38.49 \\
\hline $7 D^{* 0 p p m A S}$ & 0.55 & 0.22 & 0.27 & 0.69 & 0.26 & 0.39 & 25.79 & 40.74 \\
\hline $7 \mathrm{D} * 200 \mathrm{ppmAS}$ & 0.64 & 0.24 & 0.30 & 0.76 & 0.30 & 0.44 & 26.36 & 33.70 \\
\hline $7 \mathrm{D} * 400 \mathrm{ppmAS}$ & 0.83 & 0.28 & 0.31 & 0.88 & 0.35 & 0.37 & 24.64 & 31.76 \\
\hline
\end{tabular}

\subsubsection{Total carbohydrates (\%)}

It is clear from Table (5) that total carbohydrates percentage took the same trend like photosynthetic pigments in regard to the influence of irrigation treatments. Total carbohydrates percentage were gradually augmented as the irrigation level was sloping downward. This may be due to the fact that during the coure of drought stress active solute accumulation of compatible isolutes such as carohydrates is claimed to be an effective stress tolerance mechanism (McKersie and Lashem, 1994), these results are in line with those obtained by Azza et al., (2012) on Amaranthus tricolor.

The effect of ascorbic acid concentration on total carbohydrates percentage took a positive trend. The promotion effect of amino acids on total carbohydrates percentage took a positive trend. The promotion effect of amino acids on total carbohydrates percentage may be due to their important role of biosynthesis of chlorophyll molecules which in turn affected total carbohydrates content. Similar results were reported by Abdel Aziz et al., (2009) and Azza et al., (2011).

In respect to the interaction between different involved factors (irrigation plus ascorbic acid), the higher values were provided when spraying $200 \mathrm{ppm}$ ascorbic acid plus irrigation every 3 days in both seasons.

\subsubsection{Minerals Content}

It is evident from the data in able (6) that, generally all minerals content under investigation were gradually increase with decreasing the irrigation intervals. Regarding irrigation intervals from 3 and up to 7 days increased the $\mathrm{N}, \mathrm{P}$ and $\mathrm{K}$ percentage. This may be due to the accumulation of the minerals in the soil. These results were confirmed by Azza et al. (2007), Azza et al., (2010) and Azza et al. (2012).

Concerning the effect of ascorbic acid application on nitrogen, phosphorus and potassium, it is evident from data that the previous minerals in leaves in the two growing seasons, were increased by using ascorbic acid application. The positive effect in $\mathrm{N}$ concentration by ascorbic acid treatment could be explained by the finding of Talaat (2003) who showed that the accumulation of nitrate by ascorbic acid foliar application may be due to the positive effect of ascorbic on root growth which consequently increased nitrate absorption. In this context, the increase in P concentration by ascorbic treatments may be attributed to the postulation of Hanafy Ahmed, (1996) who mentioned the foliar spray with ascorbic acid might increase the organic acids excreted from the roots into the soil and consequently increase the solubility of most nutrients which release slowly into the rhizosphere zone where it may be utilized by the plants. In addition, Hiatt and Lowe (1967) reported that electrostatic binding of inorganic ions by organic acid is undoubtedly involved in the process of $\mathrm{K}$-ions accumulation. 
The Effect of interaction results between irrigation intervals and ascorbic acid concentrations showed that the shortest irrigation interval (3 days) + ascorbic acid at (200 ppm) treatment resulted in the highest value of $\mathrm{N} \%$ in leaves. Whereas, the shortest irrigation intervals ( 3 days) plus ascorbic acid treatment recorded the highest $\mathrm{P} \%$ in leaves. On the other hand, the highest value of $\mathrm{K}$ was obtained by irrigation intervals (5 days) plus ascorbic acid at (200 ppm) in both seasons.

Table 6: Effect of irrigation intervals and ascorbic acid on mineral contents of branches of Tecoma capensis L. plants.

\begin{tabular}{lcccccc}
\hline \multirow{2}{*}{$\begin{array}{c}\text { Characters } \\
\text { Treatments }\end{array}$} & \multicolumn{2}{c}{ Mineral of content in branches 1 } & \multicolumn{3}{c}{ Mineral of content in branches 2 } \\
\cline { 2 - 7 } No & $\mathbf{P \%}$ & $\mathbf{K \%}$ & $\mathbf{N \%}$ & $\mathbf{P \%}$ & $\mathbf{K \%}$ \\
\hline 3 Days & 0.84 & 0.15 & 0.64 & 0.93 & 0.16 & 0.77 \\
5 Days & 0.69 & 0.17 & 0.66 & 0.79 & 0.17 & 0.76 \\
7 Days & 0.60 & 0.16 & 0.57 & 0.73 & 0.16 & 0.69 \\
control & 0.61 & 0.14 & 0.54 & 0.68 & 0.15 & 0.68 \\
200ppmAS. & 0.80 & 0.16 & 0.68 & 0.91 & 0.16 & 0.79 \\
400ppmAS. & 0.72 & 0.18 & 0.64 & 0.85 & 0.17 & 0.76 \\
3D*0 ppmAS & 0.69 & 0.13 & 0.55 & 0.69 & 0.14 & 0.68 \\
3D* 200 ppm AS & 0.93 & 0.14 & 0.67 & 1.06 & 0.15 & 0.78 \\
3D* 400 ppm AS & 0.90 & 0.19 & 0.71 & 1.04 & 0.18 & 0.86 \\
5D* 0 ppm AS & 0.58 & 0.15 & 0.52 & 0.67 & 0.16 & 0.63 \\
5D*200 ppm AS & 0.83 & 0.17 & 0.80 & 0.92 & 0.17 & 0.91 \\
5D*400 ppm AS & 0.67 & 0.18 & 0.65 & 0.77 & 0.17 & 0.75 \\
7D*0 ppm AS & 0.57 & 0.14 & 0.56 & 0.69 & 0.15 & 0.72 \\
7D*200 ppm AS & 0.63 & 0.16 & 0.57 & 0.74 & 0.16 & 0.68 \\
7D*400 ppm AS & 0.60 & 0.18 & 0.57 & 0.75 & 0.17 & 0.66 \\
\hline
\end{tabular}

\section{References}

Abd-El baki, G.K, F. Siefritz, H.M. Man, H. Weiner, R.Kaldenhoff and W.M. Kaiser, 2000. Nitrate reeducates in Zea mays L.under salinity. Plant Cell Environ., 23: 515-521.

Abdelhamid, M.T., M.S.H. Sadak, U. Schmidhalter, and A. El-Saady, 2013. Interactive effects of salinity stress and nicotinamide on physiological and biochemical parameters of faba bean plant. Acta Biol. Colomb., 18: 499-510.

Abou-Leila, B., S.A. Metwally, M.M. Hussen and S.Z. Leithy, 2012. The Combined Effect of Salinity and Ascorbic Acid on Anatomical and Physiological Aspects of Jatropha Plants. Australian Journal of Basic and Applied Sciences, 6(3): 533-541.

Abou-Leila, B., S.A. Metwally, M.M. Hussen and S.Z. Leithy, 2012. The Combined Effect of Salinity and Ascorbic Acid on Anatomical and Physiological Aspects of Jatropha Plants. Australian Journal of Basic and Applied Sciences, 6(3): 533-541

Araus, J.L., M.D. Serret and G.O. Edmeades, 2012. Phenotyping maize for adaptation to drought. Front Physiol., 3: 305. PubMed: 22934056.

Azza A.M. Mazher, Sahar M. Zaghloul, Safaa A. Mahmoud and Hanan S. Siam, 2011. Stimulatory Effect of Kinetin, Ascorbic acid and Glutamic Acid on Growth and Chemical Constituents of Codiaeum variegatum L. Plants American-Eurasian J. Agric. \& Environ. Sci., 10 (3): 318-323.

Azza, A.M. Mazhar, Nahed G. Abd El Aziz and E. El.Habba, 2010. Impact of different soil media on growth and chemical constituents of Jatropha curca L. seedlings grown under water regime Journal of American Science, 6(8) 549-556.

Azza, A.M. Mazher, A.A. Yassen and Sahar, M. Zaghloul, 2007. Influence of foliar application of potassium on growth and chemical composition of Bauhinia variegata seedlings under different irrigation intervals. World. J. Agric. Sci., 3(1): 23-31.

Beltaji, M.S. Exogenous ascorbic acid (vitamin C) induced anabolic changes for salt tolerance in chickpea (Cicer arietinum L.) plants. Afr. J. Plant Sci., 2:118-123.

Bismillah, K.M., N. Hussain and M. Iqbal, 2001. Effect of water stress on growth and yield components of maize variety YHS 202. Journal of Research in Science 12: 15-18.

Blokhina, O., E. Virolaimen and V. Fagersted, 2002. Antioxidants, oxidative damage and oxygen deprivation stress: A review. Annals of Botany, 179-194. 
Blokhina, O., E. Virolanen, and M. Fagersted, 2003. Antioxidant, oxidative damage and oxygen deprivation stress A. Review Ann. Bot., 91:179-194.

Campos, H., M. Cooper, J.E. Habben, G.O. Edmeades and J.R. Schussler, 2004. Improving drought tolerance in maize: a view from industry. Field Crops Res., 90:19-34.

Chapman, H.D. and P.F. Pratt, 1978. Methods of analysis for soil, plant and water. Agric. Sci. Deprt., Univ. California, USA 309. Chem., 36: 345-347.

Cottenie, A.M., M. Verloo, L. Kiekens, G. Velghe, and R. Camerlynck, 1982. Chemical Analysis of Plant and Soil. Laboratory of Analytical and Agrochemistry. State Univ. Ghent, Belgium, 100129.

Darvishan,M., H. Moghadam, and H. Zahdi, 2013.The effect of foliar application of ascorbic acid(vitamin C) on physiological and biochemical changes of corn (Zea mays L.) under irrigation with holding in different growth stages .Maydica, 58:195-200.

Dawood, M., I. El Metwally, M.T. Abdelhamid, 2016. Physiological response of lupine and associated weeds grown at salt-affected soil to $\alpha$-tocopherol and hoeing treatments. Gesunde Pflanz., 68: 117-127.

Dubios, M., K.A. Gilles, J.K. Hamilton, P.A. Rebers and F. Smith, 1956. A colorimetric for determination of sugar and related substances. Anal Chem., 28:350-356.

El-fawakhry, F.M. and H.E. El-Tayeb, 2003. Effect of some amino acids and vitamins on chrnsymthemum production. J. Agric. Res. Alex. Univ., 8(4):755-766.

El-Sobky, E.E.M., E.M. Zadan, A.A. Abdel- Galil and H.G. Geweifel, 2014. Effect of irrigation interval, organic maturing and nitrogen fertilization level on yield and yield attributes of maizeZagazig .J. Agric. Res., 41(1): 1-20.

Farahat M.M., Azza A.M. Mazhar and Mona H. Mahgoub, 2012. Response of Khaya sengalensis seedlings intervals and foliar application of humic acid, J. Horticulture science \& Ornamental plants, 4(3):292-298.

Foyer, M.J., 1992. The antioxidant effects of thylakoid vitamin E ( $\alpha$-tocopherol). Plant Cell and Environment, 15: 381-392.

Hanafy A.A.H., 1996. Physiological studies on tiploun and nitrate accumulation in lettuce plants. J. Agric. Sci., Mansoura Univ., 21: 3971-3994.

Hashish Kh.I., E.F. Abdalla, Azza, M. Mazher, T.A. EL-Mesiry, 2014. Influence of Potassium Foliar Application on Growth and Chemical Constituents of Jatropha curcas Seedlings Grown Under Water Regime. International Journal of Academic Research, 6(2):142-147.

Hiatt, A.J. and R.H. Lowe, 1967. Loss of organic acid, amino acids, $\mathrm{K}$ and $\mathrm{Cl}$ from barley roots treated and aerobically and with metabolic inhibitors. Plant Physiol., 42: 1731-1736.

Hiatt, A.J. and R.H. Lowe, 1967. Loss of organic acid, amino acids, $\mathrm{K}$ and $\mathrm{Cl}$ from barley roots treated and aerobically and with metabolic inhibitors. Plant Physiol., 42: 1731-1736.

Khalifa, K.I., G.M.A. Mahgoub, and A.M. Tarrad, 2002. Maize hybrid as influenced by drought stress under drib irrigation at Nubaria region. J. Agric. Sci. Mansoura Univ., 27:2041-2052.

Mckersie, B.D. and Y.Y. Leshem, 1999. Salt stress In. Stress and stress, coping in cultivated plants, pp: 55-78. Kluwer Academic Pub. London.

Mckersie, B.D. and Y.Y. Leshem, 1999. Salt stress In. Stress and stress, coping in cultivated plants, Kluwer Academic Pub. London, 55- 78.

Mervat, S.S., T.A. Magdi and M.E. Abdel Kareem, 2010. Physiological response of faba bean plant to ascorbic acid grown under salinity stress. Egypt. J. Agron., 32(1): 89-106.

Mervat, S.S., T.A. Magdi and M.E. Abdel Kareem, 2010. Physiological response of faba bean plant to ascorbic acid grown under salinity stress. Egypt. J. Agron., 32(1): 89-106.

Mona, H. Mahgoub and Iman, M. Talaat, 2005. Physiological response of rose geranium (Pelarogenium graveoents L.) to phenylalanine and nicotinic acid. Annals of Agric. of Sci. Moshtohor, 43(2):807-822.

Nahed, G. Abdel Aziz and Lobna, S. Taha and Soad, M.M. Ibrahim, 2009. Some studies on the effect of puterscine, ascorbic acid and thiamine on growth, flowering and some chemical constituents of gladiolus plants at Nubaria. Ozean J. of Appl. Sci., 2(2): 169-179.

Nahed, G. Abdel Aziz, Lobna, S. Taha and Soad, M.M. Ibrahim, 2009.Some studies on the effect of puterscine, ascorbic acid and thiamine on growth, flowering and some chemical 
Nornai, R., 1982. Formula for determination of chlorophyllus pigments extracted with N, N-dimethyl formamide. Plant Physiol., 69:1376-1381.

Orabi, S.A., and M.T. Abdelhamid, 2016. Protective role of $\alpha$-tocopherol on two Vicia faba cultivars against sea water-induced lipid peroxidation by enhancing capacity of anti-oxidative system. J. Saudi Soc. Agric. Sci., 15, 145-154.

Piper, C.S., 1950. Soil and Plant Analysis. Int. Sci., Pulb, New York, 368.

Price, C.E., 1966. Ascorbic stimulation of RNA synthesis : Nature, 212, 1481.

Rady, M.M., M.S. Sadak, S.R. El-Lethy, E.M. Abdelhamid, M.T. Abdelhamid, 2015. Exogenous $\alpha-$ tocopherol has a beneficial effect on Glycine $\max (\mathrm{L}$.) plants irrigated with diluted sea water. J. Hortic. Sci. Biotechnol., 90: 195-202.

Reddy, A.R., K.V. Chaitanya and M. Vivekanandan, 2004. Drought induced responses of photosynthesis and antioxidant metabolism in higher plants. J. Plant Physiol., 161: 1189202.RNA synthesis: Nature, 212-1481.

Smirnoff, N., 1996. The function and metabolism of ascorbic acid in plants. Ann. Bot., 78: 661-669.

Snedecor G.A. and W.G. Cochran, 1976. Statistical Method. Iowa State Univ. Press, Ames.

Snell F.D. and C.T. Snell, 1949. Colorimetric Methods of Analysis. $3^{\text {rd }}$ ed. Van Nostrand, New York, USA, 785-807.

Steve, C., 2003. Tecomaria capensis (Syn.), cape honey suckle. Floridata Plant Encyclopedia, 5-7.

Talaat, N.B., 2003. Physiological studies on the effect of salinity, ascorbic acid and putrescine of sweet pepper plant. Ph.D. Thesis, Fac. Agric. Cairo Univ., Egypt.

Talaat, N.B., 2003. Physiological studies on the effect of salinity, ascorbic acid and putrescine of sweetpepper plant. Ph.D. Thesis, Fac. Agric. Cairo Univ., Egypt.

Thompson, T. and W.S. Mutshinyals, 2001. Tecoma capensis (Thumb.) spach. Walter Sisulu National Botanical Garden, 1-2.

Yaghoubian, H., H. Moghadam, and H. Zahedi, 2014. The effect of foliar application of Salicylic acid on physiological and biochemical changes of corn (Zea maysL.) under irrigation with holdingin different growth stages. Journal of Applied Science and Agriculture, 9(9): 27-34.

Youssef, A.A., Mona, H. Mahgoub and Iman, M. Talaat, 2004. Physiological and biochemical aspects of Matthiola incana L. plants under the effect of putresine and kinetin treatments. Egypt. J. Appl. Sci., 19(9B): 492-510. 